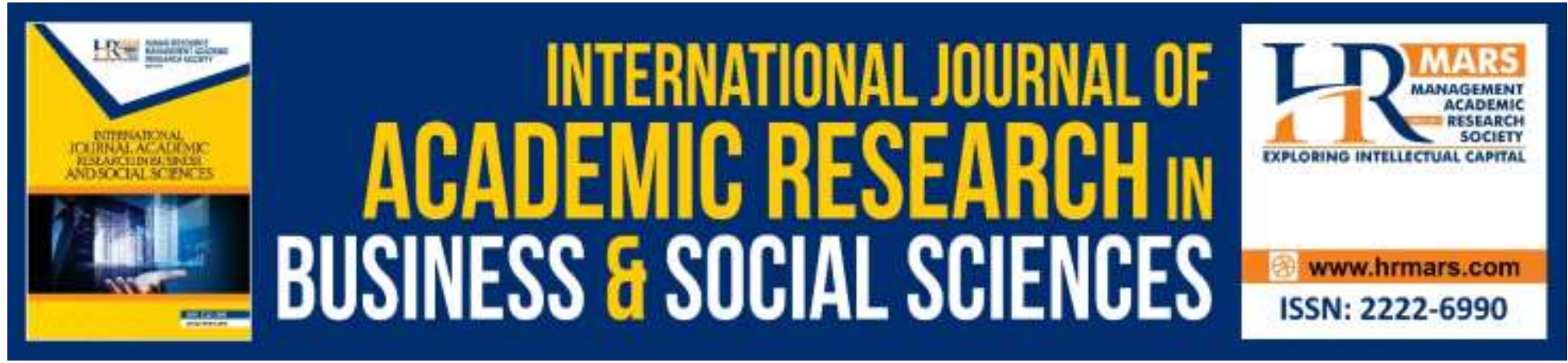

\title{
ICT Development of Community in Rural Areas
}

Syafila Kamarudin, Siti Zobidah Omar, Jusang Bolong, Mohd Nizam Osman \& Mastura Mahamed

To Link this Article: http://dx.doi.org/10.6007/IJARBSS/v9-i9/6273

DOI: 10.6007/IJARBSS/v9-i9/6273

Received: 20 June 2019, Revised: 07 July 2019, Accepted: 24 August 2019

Published Online: 04 September 2019

In-Text Citation: (Kamarudin, Omar, Bolong, Osman, \& Mahamed, 2019)

To Cite this Article: Kamarudin, S., Omar, S. Z., Bolong, J., Osman, M. N., \& Mahamed, M. (2019). ICT Development of Community in Rural Areas. International Journal of Academic Research in Business and Social Sciences, 9(9), 118-126.

\section{Copyright: (C) 2019 The Author(s)}

Published by Human Resource Management Academic Research Society (www.hrmars.com)

This article is published under the Creative Commons Attribution (CC BY 4.0) license. Anyone may reproduce, distribute, translate and create derivative works of this article (for both commercial and non-commercial purposes), subject to full attribution to the original publication and authors. The full terms of this license may be seen at: http://creativecommons.org/licences/by/4.0/legalcode

\section{Vol. 9, No. 9, 2019, Pg. 118 - 126}

Full Terms \& Conditions of access and use can be found at http://hrmars.com/index.php/pages/detail/publication-ethics 


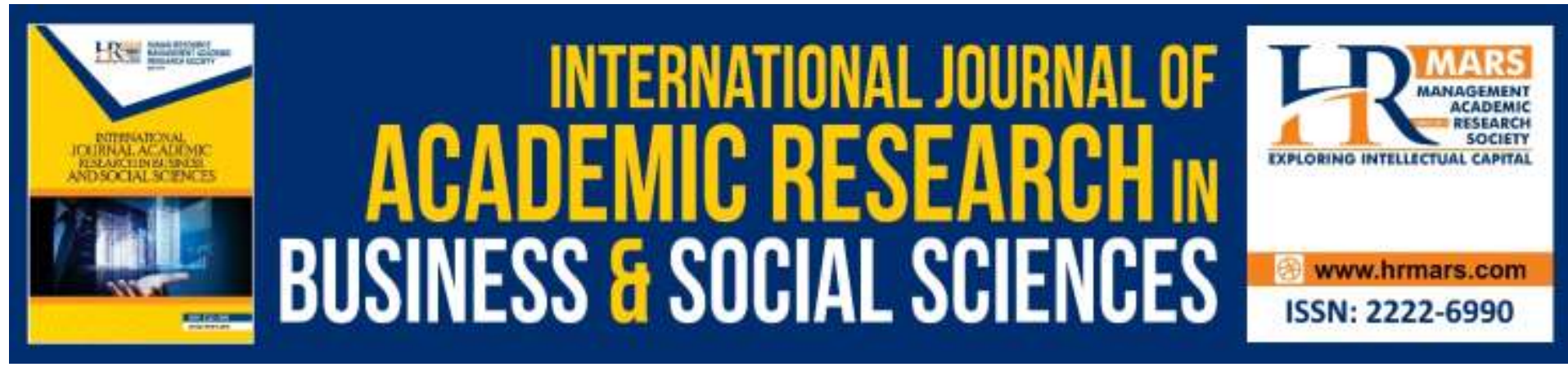

\title{
ICT Development of Community in Rural Areas
}

\author{
Syafila Kamarudin ${ }^{a}$, Siti Zobidah Omara,b, Jusang Bolong ${ }^{\mathrm{b}}$, \\ Mohd Nizam Osman ${ }^{b}$ \& Mastura Mahamed ${ }^{b}$ \\ anstitute for Social Science Studies, Universiti Putra Malaysia, 43400 Serdang, Selangor. ${ }^{b}$ \\ Department of Communication, Faculty of Modern Languages and Communication, \\ Universiti Putra Malaysia, 43400 Serdang, Selangor. \\ Email: syafila.kamarudin@gmail.com,zobidah@upm.edu.my, jusang@upm.edu.my, \\ mo_nizam@upm.edu.my, mastura.mahamed@gmail.com
}

\begin{abstract}
Information Communication Technology (ICT) is no longer limited to urban population, but it has become increasingly relevant to the rural population. The use of ICT is evident through availability of ICT services for all in Malaysia's rural areas. The internet in particular is gaining influences in the lives of rural communities in many aspects such as socially, educationally or economically is moving towards digitization. The establishment of ICT centers in rural areas has accelerated the adaptation of ICT in rural areas. Therefore, in general, this article will discuss the importance of ICT usage for rural community, and the government initiatives toward enhancing the ICT usage especially in the telecentre. The significance of having telecentres function as the centre for ICT excellence in rural areas. The telecentre provides ICT facilities such as internet and computer training room for use by rural community. Moreover, the establishment of telecentre is aiming for ICT awareness among the rural; one of the government initiatives.
\end{abstract}

Keywords: Information Communication Technology, Government, Telecentre, Rural Community, Rural Area

\section{Introduction}

Several government initiatives have been implemented to elevate Malaysia to fastest growing developing countries in the world. Rural areas are no exception in efforts of nation on planning and development programs. Telecentre as one of the government initiatives in providing ICT facilities and information services to rural communities, which is believed would benefit them in terms of socio-economic development. Such establishments equipped with complete ICT services and experience has encouraged utilization of technology for the benefit of rural communities in Malaysia.

ICT has been recognize as an effective tool for rural development. Despite this importance, there is still a huge gap between rural and urban communities in Malaysia (Hassan \& Shaffril, 2009). Moreover, Noor Sharifah (2003) has identified not many rural people in Malaysia own personal computer and internet hence potentially widen the digital divide among urban and rural areas. Digital divide can be understood as the differences 
between those who are literate and illiterate in ICT usage or those who are knowledgeable in ICT and those whom without or lack of knowledge in ICT usage. Digital divide can occur on factors such as areas, countries, ethnic groups, gender and economic status. There are numbers of key criteria that can be referred in quantifying the digital divide such as computer, ownership, access to internet, technical aspect and knowledge in ICT utilization (Sharifah, 2006).

In Malaysia, ICT development has been strengthened by the National Information and Technology Agenda (NITA) and Universal Services Provider (USP). Among the crucial objective of this establishment is to encourage and fortify ICT culture among the communities in all areas. Furthermore, Pusat Internet Desa, Medan Info Desa and National Broadband Initiative are the three main ICT projects that are initiated, and these three projects are expected to increase ICT usage among rural people. However, active use among the rural community in Malaysia remained low and need further encouragement. Malaysian Communication and Multimedia Commission (2008) have detected that only 14 percent of the rural community in Malaysia used internet in 2008. Hassan et al. (2009) on the other hand, highlighted majority of the rural community still hesitant to use ICT.

\section{Literature Review}

\section{Telecentre as a Government Initiative for Rural Communities}

Telecenters are seen to be the catalyst to foster interest in using ICT among rural communities. These have been rapidly promoted by the government as a medium to provide access to information during the past decade, especially for rural communities. Telecentre provides various ICT services, such as access to the Internet, to computers and software capabilities, to electronic commerce applications, and to public information services (Townsend et al., 2001; Masiero, 2011) with the aim of achieving a variety of development objectives (Bishop \& Bruce, 2005). This initiative also doubled as community centers used as a place for social gathering activities and interaction, learning, and mobilizing efforts in dealing with community problems and needs (Delgadillo et al., 2002).

Generally, aim of such initiative is to address the economic and social impacts of the shift to an information society. This community-based effort is deemed as crucial in provide computer access and training to underserved populations that would otherwise not have such access such as rural communities (Jinqiu et al., 2007; Lennie et al., 2005; O'Neil, 2002; Servon $\&$ Nelson, 2001). Since, the economic activities of the rural communities are mainly farming, fishery, and small-scale business, ICT initiative may help in their development. For instance, it could help to increase farmers' output, improve market reach, eliminate intermediaries, provide knowledge to improve products requirement as well as increase rural peoples' social interactions. In addition, it will also help to reduce migration of youth to towns to look for better jobs or opportunities.

\section{Information Communication Technology (ICT)}

ICT is a current phenomenon that occurs due to the needs of the development of technology. ICT consists of hardware, software, networks and media for the purposes of processing, transmission, storage and presentation of information (Sarkar, 2012). Traditional ICTs component such as television, radio, and fixed telephones line have seen a huge submerge on their existence with the advent of new ICTs such as internet, mobile phone and computer. 
Deployment of this new technology is not limited only to urban areas and has been increasingly becoming more accessible also in rural areas yet the penetration is yet optimal.

Therefore, the Internet may create a usage gap between urban and rural areas. According to Unicef (2014), there were more than 45 per cent of computer literacy rate reached among Malaysian aged between 5 to 69 years in every state with 68.6 per cent of the computer literacy rate in the urban and 42.1 per cent in rural areas respectively, resulting in a difference of 26.5 percentage points in the urban-rural gap. Knowledge gap has been described as differential derivation of knowledge; however, usage gap explains the differential in uses and activities in all fields of daily life, which is more relevant for society with regard. Dijk (2005) explained, the usage gap involves the combination of societal tendencies and technological characteristics. In addition, the researcher also mentioned that the social tendencies are sociocultural differentiation or individualization. It does relate with the increases of cost especially on the conditional aspects of access of public information and communication facilities. Different uses may be derived from the technological characteristics itself (Dijk, 2005).

\section{Function of ICT}

ICT can provide information, news and knowledge to others that will give meaningful and useful information to be used. For example, the traditional media in Malaysia has become the bridge between the government and community to form clear understanding of the government (Salman, 2010). The use of electronic media in Malaysia development has been very prominent. Government has provided information about Malaysia's development plan, strategies, and policies as well as other important information efficiently to the society. Nowadays, the Malaysian government is focusing more on Information Technology (IT) which is believed to have a potential to speed up and accelerate the nation development process. Electronic government (e-government) has been introduced in many government and administration systems to support the information age in terms of socio-economic development.

ICT has also enhanced communication ability through connecting others beyond the limit by providing enough and advanced communication infrastructure such as internet network. Via internet, the world without border allows users to relate to others twenty-four hours a day (Hashim \& Becker, 2001). The social development is being fully developed among the society. The new millennium is seeing extremely rapid increases in computer, internet and mobile phone use among developing countries including Malaysia. These new media and technologies are growing quicker rather than traditional media and mobile phones are recorded to have overtaken fixed telephones line in terms of coverage, and more internet users than daily newspapers purchased in many parts of the world (McKenzie \& Rapoport, 2007).

The Internet is part of ICT which is the world's largest interconnected environment. The interactivity of new media is difficult to be monitored as compared to traditional mass media. Realizing the potential Malaysian government had to come out with a solid ICT policy. The National IT Agenda (NITA), under the National IT Council (NITC), has introduced the foundation and framework for the utilization of ICT in transforming Malaysia into a developed nation. The transformation of ICT utilization injected into an information and knowledgeable society is at the core of NITA vision which finally added value to form knowledge-based e society among Malaysians. ICT has been identified as one of the drivers for growth which has 
moved up the value chain in information age from industry-based economy to knowledgebased economy.

\section{Roles of ICT Usage}

ICT is playing important roles on society in terms of development. The enhancement of ICT has made remarkable transformation of socio-economic environment in nations. Huge investment in developing advanced and high-tech infrastructure has been one of the government priorities to meet the increasing demand and coop with other developing countries competitively. Malaysians will benefit from the government efforts in education, industrial, health and commercial sectors to be prevalent and imperative element.

ICT also acts as a mechanism in bridging the digital divide that exists between rural and their counterpart urban areas (Bashir et al., 2011). This strategy is to accelerate rural community development by improving the living conditions of communities in rural areas. For example, by providing the rural communities with ICT facilities and services such as telecentres, it does not only close the digital gap, but it is also bringing the benefit of ICT to the rural poor. In line with the statement, Kelles-Viitanen (2005) pointed on the role of ICT which has proved that it could provide opportunities on educational and health in terms of services, and promoting democracy based on good governance which catalyst in the task of poverty reduction.

In leveraging the rural productivity, ICT awareness and support for online connectivity can contribute to rural development sustainability. Its presence also increase shared solutions between local people and communities, providing access to practical information especially in small business, financial management, weather trends and farming based practices are also some other beneficiaries which will be derived from ICT uses among rural communities. Such scenarios and benefits were found in Bangladesh Rahman et al. (2005) and in agreement by Buyukbay \& Gunduz (2011) from Turkey. Vital information such as market price, it will help to eliminate the manipulation of middlemen and improve rural income. Thus, it increases the pattern of rural folk using ICT as education retrieving tool similar to urban communities which contributed to their growing appeal to their surroundings and global happenings (Bashir et al., 2011). There will be no more issues of underserved community because of remote area with the existence of internet.

The World Bank Group (2012) reported that ICT can effectively increase business productivity, improving accountability, accelerating economic growth and overcoming poverty in any society. Supported by the statement, Thioune (2003) emphasizes ICT it could affect people's lives in different aspects. The use of ICT could positively impact on various kinds of advancement and development of society which could promote opportunities for positive development.

\section{Importance of ICT Usage for Rural Communities}

Once the ICT has been made accessible to the rural community, then, the importance of ICT usage will be seen among the rural community. The importance of ICT to the rural community are as follows:

\section{Reduced the Digital Divide}

The digital divide globally occurred between developed and undeveloped nations, whereas the national digital divide is a gap between urban and rural areas. ICT utilization has obvious 
positive outcome. Studies done by Owo (2010) reveal that ICT users are more likely to be better educated than non-users while it was found that men regularly use ICT especially computer and internet. It can be concluded that in developed and developing country, younger people use ICT more compared to the older people (Hassan et al., 2009 \& Cresci et al., 2010). In developing countries, usage of ICT can penetrate and serve the rural community better if the access is provided immensely although geographic location also can be a considerable factor; a richer region is identified to have a better ICT usage compared to the than poorer ones (Gilligan, 2005).

\section{Increased Knowledge}

Information is a powerful tool. ICT's ability to response to the informational needs of the rural community cannot be denied (Kari, 2007). This indeed will enhance their knowledge regarding everything. ICT can be the key to disseminate the important and much needed information to the community. Grimes (2000) emphasized that ICT can educate the rural community with new things. Apart from this, Rao (2004) in his study has revealed on how ICT can increase the rural community level of knowledge through ICT program in India known as Value Addition Centre (VAC). This program was design with the demands of the community; the VAC available on the network in the community native language. Through this program, rural communities are exposed continuously to numerous kinds of information and more importantly, because the program used native language, the rural people can understand the new knowledge better and faster. According more to Rao (2004), the impact of being exposed to continuous information can be seen when the community in the village able to get a higher salary.

\section{Enhanced Community Socio-Economic Level}

Doubtlessly, ICT can be the important medium to improve the socio-economic growth (BarbaSanchez et al., 2007). ICT has played a big role in promoting gender equality, enhanced people skills through the knowledge they disseminated and provide job opportunities to qualified community members; these are the good impact. On top of it, ICT can aid rural entrepreneurs in enhancing their productivity. Referring to Cecchini and Raina (2002), through ICT farmers instantly can know how much they earned during harvest and computer has allowed on a systematic management and reduces cost in fertilizer stock. ICT has the potential for many applications in the rural area, including allowing farmers to access to agricultural information that could uplift their quality of life and provide better access to government services.

\section{Enhanced Rural Community Literacy Level}

Use of ICT in literacy education can assist in evolving the literacy skills due to its abilities and potentials (Rossiter \& Bagdon, 1999). ICT can response at instance to the learners' needs can spearhead learning process and learn effectively compared to those who learn without ICT. Through ICT, the learners' creativity can be maximized as the learners can perform their task on their own, at their own pace which mounting both oral and writing skills and at the same time as learning to read. Moreover, ICT can be attractive especially for the first-time users, so it can motivate learners to involve in literacy education and can stimulate them to go on with the learning process. This process can enhance the degree of retention of literacy among the rural community (Ellie, 2006). 


\section{Methodology}

As this study is a review study and based on document analyzes and reviews of literature, several electronic databases were searched such as Scopus, Emerald, Wiley, SpringerLink and Sage Pub. Subsequently, drawing on online thesaurus and several previous studies, several keywords similar to ICT development, including "ICT utilization", "digital development", technology development", and combinations of these keywords were referred in the searching process. Thirdly, to enlarge the searching process, there are several complementary techniques were practiced in researchers' searching efforts (Shaffril et al., 2018). Citation tracking is one of them and it was implemented by identifying related articles based on those papers citing the paper being studied. Reference searching is another technique, and the researchers examined the reference lists in the selected articles for other articles. Both techniques - citation tracking and reference searching, assists in reducing the risk of missing relevant information. The final stage, an unstructured search (Cooper, 1998) using Scopus, Google and Google Scholar was practiced in an effort to identify additional studies of relevance.

\section{Conclusion and Recommendation}

Briefly, the presence of ICT is very useful for rural community because they gain similar advantages as the people living in the city. The use of ICT as in a telecentre can be used to explain the functions and explore the roles of ICT more clearly.

ICT development in Malaysia is highly emphasized by the government and this is proven through the allocation provided for ICT in the Eighth Malaysia Plan and Ninth Malaysia Plan. Such allocation for ICT development has been proven to bring impact on the rural development. Issues such as digital divide, poverty and unemployment can be solved by using ICT. The importance of having a systematic and effective planning designed for rural communities to promote ICT literacy need to be at the forefront. Among the benefits that ICT can offer are increasing knowledge, enhance literacy level, reducing digital divide and enhancing the socio-economic level.

ICT services in telecentre should be continued in the future to sustain the accessibility and availability of rural community with global society. This is because the use of the telecentre and ICT services provided is still relevant to rural communities. Furthermore, by ensuring each telecentre in Malaysia is facilitated with ICT services, it will produce more rural communities with IT literate thus enhancing income generation supporting the Inland Revenue.

\section{Acknowledgement}

This study would like to thank Universiti Putra Malaysia for providing the research grant GPIPS/2017/9547200.

\section{References}

Rahman, A. M., Mahfuz, M. U., Ahmed, K. M., \& Rajatheva, R. M. A. P. (2005). ICT based sustainable rural business opportunities in developing countries: A wireless-networked RCP-RAP approach. American Journal of Applied Science, 2(8), 1256-1260.

Barba-Sánchez, V., Martínez-Ruiz, M. D. P., \& Jiménez-Zarco, A. I. (2007). Drivers, benefits and challenges of ICT adoption by small and medium sized enterprises (SMEs): a literature review. Problems and Perspectives in Management, 5(1), 103-114. 
Bashir, M. S., Samah, B. A., Emby, Z., Badsar, M., Shaffril, H. A. M., \& Aliyu, A. (2011). Information and communication technology development in Malaysia: Influence of competency of leaders, location, infrastructures and quality of services on telecentre success in rural communities of Malaysia. Australian Journal of Basic and Applied Science, 5(9), 1718-1728.

Bishop, A. P., \& Bruce, B. (2005). Community informatics: Integrating action, research and learning. Bulletin of the American Society for Information Science and Technology, 31(6), 6-10.

Buyukbay, E. O., \& Gunduz, O. (2011). An investigation on computer and internet use for agricultural development in rural areas: A case study for Tokat Province in Turkey. African Journal of Biotechnology, 10(56), 1879-1886.

Cecchini, S., \& Raina, M. (2002). Warana: The case of an Indian rural community adopting ICT. Information Technology in Developing Countries Working Paper. [online]. Retrieved October 13, 2018, from http://www.comminit.com/en/node/147613/308

Cresci, M. K., Yarandi, H. N., \& Morrell, R. W. (2010). The digital divide and urban older adults. Computers, Informatics, Nursing, 28(2), 88-94.

Delgadillo, K., Gómez, R., \& Stoll, K. (2002). Community Telecentres for Development: Lessons from Community Telecentres in the Latin America and the Caribbean: International Development Research Centre (IDRC), Canada.

Ellie, M. (2006). Using ICT to develop literacy. Booklet of United National Educational, Scientific and Cultural Organization (UNESCO). Retrieved 14 October 2018 from http://unesdoc.unesco.org/images/0014/001464/146426e.pdf.

Gilligan, R. (2005). Questioning the "rural" adoption and use of ICTs. Computer Science, 32(5), 155-167.

Grimes, S. (2000). Rural areas in the information society: Diminishing distance or increasing learning capacities? Rural Studies, 16(1), 13-21.

Hashim, R., \& Becker, G. (2001). Internet Malaysia. Bangi (Malaysia): Department of Communication, UKM.

Jinqiu, Z., Xiaoming, H., \& Banerjee, I. (2007). The sustainability of public internet access centres: lesson learned from ICT projects in rural China. Paper presented at conference on Empowering Rural Communities through ICT Policy and Research, December 15-17, 2007, Chennai, India.

Kari, H. K. (2007). Availability and accessibility of ICT in the rural communities of Nigeria. The Electronic Library, 25(3), 363-372.

Kelles-Viitanen, A. (2005). The role of ICT in governing rural development. In: IFAD Workshop: What are the innovation challenges for rural development, Rome, 15(17),11-14.

Lennie, J., Hearn, G., Simpon, L., \& Kimber, M. (2005). Building Community Capacities in Evaluating Rural IT Projects: Success Strategies from the LEARNERS Project. International Journal of Education \& Development using ICT 1(1), 13-31.

Malaysian Communication and Multimedia Commission. (2008). Q4, 2008, Communication and Multimedia, selected facts and figures. Retrieved 14 October 2018 from http://www.skmm.gov.my/facts_figures/stats/index.asp.

Masiero, S. (2011). Financial vs Social Sustainability of Telecentres: Mutual Exclusion or Mutual Reinforcement? The Electronic Journal on Information Systems in Developing Countries (EJISDC), 45(3), 1-23. 
McKenzie, D., \& Rapoport, H. (2007). Network effects and the dynamics of migration and inequality: theory and evidence from Mexico. Journal of Development Economics, 84(1), 1-24.

Hassan, M. S., \& Shaffril, H. A. M. (2009). Internet usage among agro-based entrepreneurs: Can it affect productivity. Agriculture and Social Science, 5(3), 61-66.

Hassan, M. A., Shaffril, H. A. M., Samah, B. A., Ali, S. S., \& Hassan, M. S. (2009). Media massa, ICT, komuniti tani dan pengembangan pertanian: usaha ke arah memperkasa sektor pertanian di Malaysia. Dalam Bahaman, A. S., Jegak, U., \& Khatijah, A. (eds). Media dan Pengembangan Pertanian ke arah Memperkasakan Komuniti Luar Bandar (pp. 32-48). Penerbit UPM, Serdang.

Sharifah, N. S. S. (2003). Model planning on traditional village in Peninsular Malaysia. Paper presented at Rural Planning Center, Faculty of Alam Bina, UTM. Technology University of Malaysia Publisher, Skudai, Johor.

Sharifah, N. S. S. (2006). ICT centres for rural community in Peninsular Malaysia. Inaugural Lecture Series. Technology University of Malaysia Publisher, Skudai, Johor.

O'Neil, D. (2002). Assessing Community Informatics: A Review of Methodological Approaches for Evaluating Community Networks and Community Technology centres. Internet Research: Electronic Networking Applications and Policy, 12(1), 76-102.

Owo, N. J. (2010). Gender and development: Nigeria as a case study. Journal of Sustainable Human Development Revision, 2, 81-91.

Rossiter, D., \& Bagdon, K. (1999). Embedding the acquisition of technological literacy: A case study. Educational Technology \& Society, 2(4), 82-91.

Sarkar, S. (2012). The role of information and communication technology (ICT) in higher education for the 21 st century. Science, 1(1), 30-41.

Rao, S. (2004). Role of ICTs in India's rural community information systems. Info, 6(4), 261269.

Salman, A. (2010). ICT, the new media (Internet) and development: Malaysian experience. The Innovation Journal: The Public Sector Innovation Journal, 15(1), 5-10.

Servon, L. J., \& Nelson, M. K. (2001). Computer Technology Centres: Narrowing the Digital Divide in Low-Income, Urban Communities. Journal of Urban Affairs, 23(3-4), 279-290.

Thioune, R. M. C. (2003). Information and communication technologies for development in Africa: Opportunities and challenges for community development. Volume 1. Ottawa: IDRC. Available: http://www.idrc.ca

Townsend, M. S., Peerson, J., Love, B., Achterberg, C., \& Murphy, S. P. (2001). Food insecurity is positively related to overweight in women. The Journal of Nutrition, 131(6), 17381745.

Unicef. (2014). Exploring the Digital Landscape in Malaysia: Access and use of digital technologies by children and adolescents. Retrieved 15 October 2018 from https://www.unicef.org/malaysia/UNICEF_Digital_Landscape_in_Malaysia-FINALlowres.pdf

Dijk, V. J. A. (2005). The deepening divide: Inequality in the information society. Thousand Oaks: Sage Publications.

World Bank Group. (2012). Gender equality and development. Retrieved 10 October 2018 From https://siteresources.worldbank.org/INTWDR2012/Resources/77781051299699968583/7786210-1315936222006/Complete-Report.pdf 